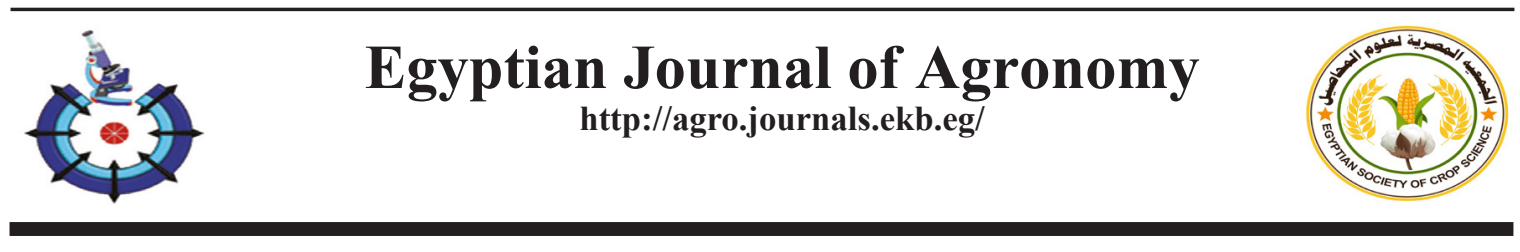

\title{
Response of Lentil to Crude Humates and Rhizobacteria Inoculation under Calcareous Soils Conditions
}

\author{
Yasser A. El-Tahlawy ${ }^{(1) \#}$, Salwa A.A. Hassanen ${ }^{(2)}$ \\ (1) Agricultural Microbiology, Department, Soil, Water and Environmental Research \\ Institute (SWERI), Agricultural Research Center (ARC), Giza, Egypt; (2)Central \\ Laboratory of Organic Agriculture, Agricultural Research Center (ARC), Giza, \\ Egypt.
}

\begin{abstract}
$\mathbf{T}$ WO field experiments were conducted, during two cropping seasons, to study the cultivation of two lentil cultivars, namely Sina-1 and Giza-9, under a calcareous soils condition. The cultivation was done using liquid crude humates, extracted from compost, as organic fertilizer or consortium of some PGPR including Serratia marcescens, Bacillus megaterium and Pseudomonas fluorescens as biofertilizer against mineral fertilization. The experiments were designed in a split block design. The humate application or PGPR stimulate microbial count and dehydrogenase activity, in the rhizosphere, against a full dose of mineral fertilizers. In general, high rate of humates followed by a full dose of nitrogen recorded maximum values with respect to the plant height, shoot dry weight and leaf area at vegetative state. Concerning to the dark green color index (DGCI), the plants significantly captured more greenness due to applying a full dose of nitrogen followed by a high dose of humate $(20 \mathrm{~L} /$ fed) with Giza 9 compared with Sinai 1 cultivar. The maximum values were recorded by Giza 9 cultivar fertilized with a high dose of humate followed with that of a full dose of nitrogen for pods and seeds number and seeds yield during both cropping seasons. However, the effect of the co-inoculation with PGPR and Rhizobium boosted the yield components against the absolute control and treatment of individual Rhizobium + activation dose of nitrogen for the same parameters. Based on results it may be concluded that cultivation of Giza 9 cultivar with the application of crude humate at $20 \mathrm{~L} / \mathrm{fed}$ and Rhizobium inoculation is being favored under calcareous soil.
\end{abstract}

Keywords: Biofertilizers, Calcareous Soils, K-humates, Lentil plants.

\section{Introduction}

Lentil (Lens culinaris Medik.) is one of the winter season pulse crops which has a considerable nutritive value for human beings present in their seeds which contains about $21-31 \%$ protein, $43.4-69.9 \%$ total carbohydrate, $0.7-4.3 \%$ fat, $5.0-26 \%$ fiber and $2.2-4.2 \%$ ash (Joshi et al., 2017). Furthermore, like any leguminous crop, lentil cultivation can share in the sustainable development of agroecosystems. Its cultivation has a vital role in nitrogen cycling because it can be fix biologically about $85 \%$ of its required nitrogen from the surrounding atmosphere $14.39 \%$ of nitrogen is drawn from soil source
(Gan et al., 2016; Kabir et al., 2019). In Egypt, statistics showed that lentils' production in 2017 was only 480 tonnes which was produced from 235 ha $(\approx 580.7 \mathrm{fed})$ harvested area (FAOSTAT, 2019).

Humic substances (HS), including humic and fulvic acids, have been classified as a natural product of organic material occurring in or extracted from decayed/decaying biomatter (MacCarthy, 2001). It is being extracted, using an alkaline solution, from various resources, including sub-bituminous coals, lignites, peat, soils, composts, and raw organic wastes (Rose et al., 2014). Many studies reported that the humic

\#Corresponding author email: yasser.eltahlawy@hotmail.com

Received 12/2/2021; Accepted 17/4/2021

DOI: 10.21608 /agro.2021.62856.1247

C2021 National Information and Documentation Center (NIDOC) 
acids, the most active HS component, derived from composted materials significantly perform better than those derived from other sources such as leonardite, lignite, and peat in plant growth promotion (Arancon et al., 2006; Azcona et al., 2011). Humates are salts of humic and fulvic acids, such as the ammonium humates, potassium fulvate, and the potassium humates, characterized by their solubility and thus more reactive in soils (Lyons \& Genc, 2016). Many practices such as crop rotation, adequate fertilization, legumes planting, organic fertilizers including manuring with animal or green manures, and microorganism's inoculation effectively maintain an acceptable amount of humic substances in soils. However, they have an indirect effect, timeconsuming, wasteful, and costly, making humates were preferably added directly into soils as is done with fertilizers (Ibrahim \& Ali, 2018). The HS indirectly stimulate the plant growth through modulating some properties of cultivated soil, including the metabolism of microorganisms, nutrients availability, increased $\mathrm{pH}$ buffering, cation exchange capacity, and physical structure or directly by increasing biological membrane permeability as well as affecting plant metabolism by acting as hormone-like substances (Trevisan et al., 2010; Muscolo et al., 2013; Rose et al., 2014).

Biological preparations, containing one or more culturable microorganisms and perform beneficial actions toward the plant growth, are commonly announced as biofertilizers (Borkar, 2015). Such included microorganisms are termed as Yield-Increasing Bacteria (YIB) (Shen, 1997); Plant growth-promoting and bioprotecting rhizobacteria (PGPBR) (Luz, 2001); Plant Health Promoting Rhizobacteria (PHPR) (Reimann \& Sikora, 2003); Plant GrowthPromoting Microbes (PGPM) (Gangwar et al., 2017) and popularly as plant growth-promoting rhizobacteria (PGPR) (Castro-Sowinski et al., 2007; Lugtenberg \& Kamilova, 2009; Etesami \& Maheshwari, 2018). The biofertilizers could stimulate plant growth using one or more active mechanisms resulting in direct or indirect action. The direct action includes symbiotic/nonsymbiotic biological nitrogen fixation, phosphate and/or potassium solubilization, phytohormones, exopolysaccharides and/or siderophores production as well as rhizoremediation. On the other hand, they act indirectly through various helpful processes that make the plant to grow under abiotic stress actively or biotic stress via disease resistance, antibiosis, induced systemic resistance, production of protective enzymes and/ or output of volatile organic compounds (VOCs) (Jha \& Saraf, 2015; Gouda et al., 2018; Singh, 2018).

More than $30 \%$ of the earth's surface is covered with calcareous soils, where calcium carbonate $\left(\mathrm{CaCO}_{3}\right)$ contents up to $95 \%$ (Marschner, 1995). They are formed naturally in arid/semi-arid and humid/semi-humid regions. In Egypt, the calcareous soils are around 0.65 million feddans which constitute about 25-30\% of the total area (El-Zohri et al., 2017; Taalab et al., 2019). According to Elgabaly (1973), high calcium carbonate levels affect the soil properties concerned with plant growth due to plant nutrients' availability. However, the farming of calcareous soils for cultivation requires particular sustainability and environmental considerations, such as cropping system and/or fertilization. Cultivation of leguminous crops with natural or biological-based preparations could be a vital option to sustain such concerns.

The current work's motivation was to study the potential cultivation of lentil plants under calcareous soil by applying some PGPR mixture as a biofertilizer or crude humates, extracted from compost, as natural organic fertilizer.

\section{Materials and Methods}

\section{Site description and soil}

Field experiment was conducted during 2018/2019 and 2019/2020 cropping seasons for at El-Nubaria, El-Behira Governorate, Egypt (latitude $30^{\circ} 30^{\prime} 1.4^{\prime \prime} \mathrm{N}$, and longitude $30^{\circ} 19^{\prime}$ $10.9^{\prime \prime} \mathrm{E}$, and mean altitude $27 \mathrm{~m}$ above sea level). This experimental location has aspects of an arid climate that prevailed with cold and hot weather of winter and summer seasons. Table 1 indicates some meteorological features during growing seasons of 2018/2019 and 2019/2020 for the experimental area.

This information was received from the central laboratory of meteorology (CLM), the Ministry of Agriculture. The soil was sampled from 0-20 $\mathrm{cm}$ layer, air-dried, and passed through a $2-\mathrm{mm}$ sieve, analyzed as described by (Piper, 1950; Black et al., 1956). Table 2 outlines some mechanical, physicochemical, and biological characteristics of the experimental soil. 
TABLE 1. Some meteorological data about the experimental location

\begin{tabular}{|c|c|c|c|c|c|c|c|c|c|}
\hline \multirow{2}{*}{$\begin{array}{l}\text { Growing } \\
\text { seasons }\end{array}$} & \multirow[t]{2}{*}{ Month } & \multirow{2}{*}{$\begin{array}{c}\text { Solar } \\
\text { radiation } \\
\left(\mathrm{W} / \mathbf{m}^{2}\right)\end{array}$} & \multirow{2}{*}{$\begin{array}{c}\text { Precipitation/ } \\
\text { rainfall } \\
(\mathbf{m m})\end{array}$} & \multicolumn{2}{|c|}{$\begin{array}{c}\text { Wind speed } \\
(\mathrm{m} / \mathrm{sec})\end{array}$} & \multicolumn{3}{|c|}{ Temperature $\left({ }^{\circ} \mathrm{C}\right)$} & \multirow{2}{*}{$\begin{array}{c}\text { Relative } \\
\text { humidity } \\
(\%)\end{array}$} \\
\hline & & & & Aver. & Max. & Aver. & Min. & Max. & \\
\hline \multirow{6}{*}{$2018 / 2019$} & November & 46.04 & 16.91 & 2.71 & 5.95 & 20.50 & 10.88 & 31.36 & 60.20 \\
\hline & December & 49.18 & 20.91 & 2.06 & 5.64 & 20.52 & 9.55 & 23.28 & 63.67 \\
\hline & January & 51.56 & 16.29 & 3.06 & 6.83 & 17.19 & 7.76 & 24.27 & 66.61 \\
\hline & February & 67.49 & 12.92 & 2.87 & 6.73 & 16.67 & 7.53 & 26.51 & 57.46 \\
\hline & March & 95.42 & 5.39 & 3.25 & 6.66 & 17.64 & 8.81 & 28.77 & 57.39 \\
\hline & April & 111.97 & 1.17 & 3.16 & 8.22 & 23.10 & 11.74 & 30.87 & 52.84 \\
\hline \multirow{6}{*}{$2019 / 2020$} & November & 47.00 & 17.27 & 2.70 & 5.58 & 18.76 & 13.79 & 25.18 & 60.48 \\
\hline & December & 50.36 & 21.81 & 2.59 & 4.93 & 14.41 & 9.88 & 20.47 & 63.97 \\
\hline & January & 50.10 & 16.04 & 2.46 & 6.07 & 13.60 & 8.01 & 18.72 & 61.65 \\
\hline & February & 67.91 & 13.42 & 2.74 & 6.55 & 14.65 & 8.21 & 19.64 & 58.46 \\
\hline & March & 94.03 & 5.71 & 2.82 & 6.00 & 16.25 & 10.48 & 22.09 & 60.87 \\
\hline & April & 111.74 & 2.58 & 2.74 & 8.24 & 19.69 & 12.87 & 26.33 & 53.04 \\
\hline
\end{tabular}

TABLE 2. Some of the physicochemical and biological properties of the soil

\begin{tabular}{|c|c|c|}
\hline Soil property & Season $(2018 / 2019)$ & Season $(2019 / 2020)$ \\
\hline \multicolumn{3}{|l|}{ Mechanical analysis } \\
\hline Sand $(\%)$ & 52.1 & 51.2 \\
\hline Silt $(\%)$ & 23.7 & 24.3 \\
\hline Clay $(\%)$ & 24.2 & 24.5 \\
\hline Texture grade & Sandy Clay Loam & Sandy Clay Loam \\
\hline $\mathrm{CaCO}_{3}(\%)$ & 20.30 & 19.60 \\
\hline Saturation percent (SP) (\%) & 27.40 & 28.50 \\
\hline $\mathrm{pH}$ (soil paste) & 8.60 & 8.40 \\
\hline $\mathrm{EC}\left(\mathrm{dS} \mathrm{m} \mathrm{m}^{-1}\right.$, at $\left.25^{\circ} \mathrm{C}\right)$ & 1.02 & 1.06 \\
\hline \multicolumn{3}{|l|}{ Soluble cations (meq $\mathrm{L}^{-1}$ ) } \\
\hline $\mathrm{Ca}^{++}$ & 2.59 & 2.42 \\
\hline $\mathrm{Mg}^{++}$ & 1.55 & 1.57 \\
\hline $\mathrm{Na}^{+}$ & 4.21 & 4.25 \\
\hline $\mathrm{K}^{+}$ & 0.14 & 0.16 \\
\hline \multicolumn{3}{|l|}{ Soluble anions (meq $\mathrm{L}^{-1}$ ) } \\
\hline $\mathrm{CO}_{3}=$ & 0.00 & 0.00 \\
\hline $\mathrm{HCO}_{3}^{-}$ & 2.41 & 2.43 \\
\hline $\mathrm{Cl}^{-}$ & 3.98 & 3.81 \\
\hline $\mathrm{SO}_{4}=$ & 2.10 & 2.17 \\
\hline Organic matter $\quad(\%)$ & 0.33 & 0.40 \\
\hline Total-N (\%) & 0.014 & 0.016 \\
\hline Total soluble- $\mathrm{N}\left(\mathrm{mg} \mathrm{kg}^{-1}\right)$ & 10.31 & 12.13 \\
\hline Available-P $\quad\left(\mathrm{mg} \mathrm{kg}^{-1}\right)$ & 3.94 & 3.51 \\
\hline Available-K & 112.30 & 114.62 \\
\hline \multicolumn{3}{|l|}{ Total microbial counts ( $\mathrm{cfu} \mathrm{g}^{-1}$ dry soil) } \\
\hline Bacteria & $13 \times 10^{5}$ & $18 \times 10^{5}$ \\
\hline Actinobacteria & $19 \times 10^{4}$ & $21 \times 10^{4}$ \\
\hline Fungi & $8 \times 10^{3}$ & $11 \times 10^{3}$ \\
\hline Dehydrogenases ( $\mu \mathrm{g}$ TPF $\mathrm{g}^{-1}$ dry weight/day) & 83 & 92 \\
\hline
\end{tabular}




\section{Lentil seeds}

Two cultivars of lentil, namely Giza 9 and Sinai 1 were obtained by Food Legume Research Program, Field Crops Research Institute (FCRI), Agricultural Research Center (ARC), Giza, Egypt.

\section{Biofertilizer preparation}

The biofertilizer was formulated as Rhizobium leguminosarum strains (TAL168 and ICARDA139) as well as a consortium of some PGPR containing local isolates of Serratia marcescens, Bacillus megaterium, and Pseudomonas fluorescens, which supplied by Agricultural Microbiology Department, Soils, Water and Environment Research Institute (SWERI), Agricultural Research Center (ARC), Giza, Egypt. Each microorganism was cultured on a specific media. Then, equal portions of all mixed was carried on sterilized vermiculite contained $10 \%$ Irish peat up to $60 \%$ of water holding capacity and packed into polyethylene bags used as seed inoculant. Yeast extract mannitol (YEM) (Vincent, 1970), Peptone glycerol (Grimont \& Grimont, 2006), nutrient and King' s-B media (Atlas, 2010) were used as a broth for microbial growth of $R h$. Leguminosarum, S. marcescens, B. megaterium, and $P$. fluorescens, respectively.

\section{Crude humates extraction}

Potassium-humates was extracted from compost as previously proceeded by Palanivell et al. (2013) with some modification. Agric. Microbiol. Dept., SWERI, ARC, Giza, Egypt provided the used compost. The mature compost was soaked into $0.1 \mathrm{M} \mathrm{KOH}$ solution in a polyethylene bucket in a ratio of 1:10 $(\mathrm{w} / \mathrm{v})$ for $24 \mathrm{hrs}$. with frequent stirring at room temperature. The dark-colored supernatant liquid, including a mixture of crude humate and fulvate, was decanted and filtered using stainless steel gauze of 20 Mesh to separate crude humin. The supernatant liquid's $\mathrm{pH}$ was adjusted to 7.5 using $6 \mathrm{M} \mathrm{H}_{2} \mathrm{SO}_{4}$ and stored at room temperature for further application. Some physical, chemical and biological properties of the used compost were assayed according to Page et al. (1982), as shown in Table 3.

\section{Experiment layout and management}

Two field experiments were designated using a split-plot design, with four replicates, in which the lentil varieties, viz. Giza 9 or Sinai
1 were included in the main plots while the following treatments were randomly assigned to the subplots: $\mathrm{T} 1=$ Control (without NPK or biofertilizers); $\mathrm{T} 2=$ Full dose NPK; T3= Rhizobium inoculation + nitrogen activation dose (20kg N/fed.); T4= Rhizobium inoculation + nitrogen activation dose + consortium of PGPR; T5 $=$ Rhizobium + nitrogen activation dose + crude humates at rate $10 \mathrm{~L} / \mathrm{fed}$. and $\mathrm{T} 6=$ Rhizobium + nitrogen activation dose + crude humates at rate $20 \mathrm{~L} / \mathrm{fed}$.

TABLE 3. Some physical, chemical, and biological properties of the used compost

\begin{tabular}{|c|c|c|}
\hline Property & $\begin{array}{c}\text { Season } \\
(2018 / 2019)\end{array}$ & $\begin{array}{c}\text { Season } \\
(2019 / 2020)\end{array}$ \\
\hline $\begin{array}{l}\text { Bulk density } \\
\left(\mathrm{kg} \mathrm{m}^{-3}\right)\end{array}$ & 474.9 & 4777.2 \\
\hline $\mathrm{pH}(1: 10 \mathrm{w})$ & 7.71 & 7.53 \\
\hline $\mathrm{EC}\left(\mathrm{dS} \mathrm{m} \mathrm{m}^{-1}\right.$ at $\left.25^{\circ} \mathrm{C}\right)$ & 4.18 & 4.26 \\
\hline Organic matter $(\%)$ & 45.71 & 42.68 \\
\hline Total nitrogen (\%) & 1.25 & 1.18 \\
\hline $\mathrm{C} / \mathrm{N}$ ratio & 21.20 & 20.97 \\
\hline Total phosphorus (\%) & 0.47 & 0.49 \\
\hline Total potassium (\%) & 1.53 & 1.37 \\
\hline $\begin{array}{l}\text { Dehydrogenases } \\
\text { ( } \mu \mathrm{g} \mathrm{TPF} \mathrm{g}^{-1} \text { dry weight/ } \\
\text { day) }\end{array}$ & 301.21 & 296.53 \\
\hline $\begin{array}{l}\text { Seed germination test } \\
\text { of cress seeds }(\%)\end{array}$ & 91 & 93 \\
\hline
\end{tabular}

Lentil seeds were sown on $14^{\text {th }}$ and $17^{\text {th }}$ November of 2018 and 2019 years, respectively, by hand-drilled at a seeding rate of $60 \mathrm{~kg} \mathrm{fed}^{-1}(1$ hectare $=2.38$ feddan). Each plot contained ten rows $(0.3 \mathrm{~m}$ width $\times 3 \mathrm{~m}$ long $)$ allocated into a plot area of $9 \mathrm{~m}^{2}$ and with $2 \mathrm{~cm}$ between plants to give 300 plants $/ \mathrm{m}^{2}$ for plant density. All treatments received compost at a rate of 5 ton/fed, superphosphate fertilizer $\left(15 \% \mathrm{P}_{2} \mathrm{O}_{5}\right)$ at a $200 \mathrm{~kg} / \mathrm{fed}$, and potassium sulfate $\left(48 \% \mathrm{~K}_{2} \mathrm{O}\right)$ at a rate of $50 \mathrm{~kg} / \mathrm{fed}$. On the other hand, ammonium sulfate $(20.5 \% \mathrm{~N})$ was applied at rates of 40 or $20 \mathrm{~kg} \mathrm{~N} / \mathrm{fed}$ as full or activation dose, respectively. The bio fertilization proceeded as seed inoculant at a rate $300 \mathrm{~g}$ per $30 \mathrm{~kg}$ seeds using Arabic gum as an adhesive agent. The plants were treated with crude humates as a soil drench at doses of 5 or $10 \mathrm{~L} \mathrm{fed}^{-1}$ at 15 and 30 days after sowing. The plants were irrigated three times including pre-sowing irrigation and other two irrigations before flowering and at pod-filling stages, respectively. The herbicide 
"grassagard" was sprayed at pre-emergence at a rate of $1 \mathrm{~kg}$ product $/ \mathrm{fed}$, to control broad-leaved weeds. After that, hand weeding was undertaken as necessary.

\section{Rhizosphere biology}

The total number of soil bacteria in plants rhizosphere was estimated based on serial 10-fold dilutions using the pour plate method using soil extract agar (Atlas, 2010). The plates were incubated at $28^{\circ} \mathrm{C}$ in the dark, and the colony-forming unit $(\mathrm{CFU})$ was recorded after one week.

Dehydrogenase enzyme was measured, in plants rhizosphere, based on the reduction of 2,3,5-triphenyl tetrazolium chloride (TTC) to the red-colored formazan (TPF), which extracted with methanol and photometrically measured at $485 \mathrm{~nm}$ (Casida, 1977).

\section{Plant biometric traits}

At vegetative state (50 DAS), the morphology of plants was described as plant height, shoot dry weight, leaf and root area, and dark green color index (DGCI). For each treatment, fresh leaves of the same maturity stage (third leave from the top) were picked up, and roots were detached. The leaves and roots images were captured with 300 dots per inch (dpi) resolution using a flatbed scanner (HP Scanjet G2710). The images were processed to extract values of RGB using Adobe Photoshop CS6 Ver. 13-Extended.

The dark green color index (DGCI) was calculated from hue, saturation, and brightness (HSB) levels, according to Karcher \& Richardson (2003). The leaf area and root area were measured using the number of pixels (Baker et al., 1996). Nodulation was assayed in terms of nodules number and its dry weight.

At the reproductive stage, plant height, days to 50 , or $90 \%$ flowering and branches numbers. The yield and its component were recorded at the harvesting stage in terms of pods (numbers plant ${ }^{-1}$ ); seeds (numbers plant $\left.{ }^{-1}\right)$; seeds yield $\left(\mathrm{g} \mathrm{plant}^{-1}\right)$; 1000-seeds weight (g) and seed yield ( $\mathrm{ardab} / \mathrm{fed}$.).

\section{Nutritional status}

Wet digestion of oven-dried plant shoots $\left(70^{\circ} \mathrm{C}\right.$ for $48 \mathrm{hrs}$.), at vegetative state, was performed using concentrated sulphuric acid and perchloric acid as a catalyst. Total nitrogen was determined using the micro-Kjeldahl method; phosphorus was determined spectrophotometrically using ammonium molybdate and stannous chloride reagents, while potassium was determined using a Flame photometer (Chapman \& Pratt, 1961).

\section{Statistical analysis}

Statistical analysis of data was done using analysis of variance (ANOVA) according to the methods described by Snedecor \& Cochran (1980). The comparisons between treatment means were made by the least significant difference test (LSD) at $\mathrm{P} \leq 0.05$. The analysis was performed using CoStat program ver. 6.4, CoHort software.

\section{$\underline{\text { Results and Discussion }}$}

\section{Rhizosphere biology}

Data pertaining to rhizosphere biology are presented in Table 4 in terms of total bacteria count and dehydrogenase activity.

A non-significant variation was recorded due to the different cultivars of lentils. On the other hand, the application of humates or PGPR enhanced better population of the bacteria. It stimulated the plant's rhizosphere's biological activity compared with control (T1) or full dose of nitrogen (T2), which prohibited it. The higher rate $(20 \mathrm{~L} / \mathrm{fed}$.) of humates recorded the maximum bacteria count or biological activity of the rhizosphere to the tune of $3.47 \times 10^{7}$ and $4.05 \times 10^{7} \mathrm{CFU}$ or 67.22 and $72.95 \mu \mathrm{g} \mathrm{TPF} / \mathrm{g}$ dry soil/h during two successive seasons, respectively.

The similar trend of dehydrogenase activity, with a bacterial count, appears to be a useful criterion for the characterization of soil biological status and the prediction of overall soil biological activity involved in nutrient cycling (Kumar \& Maiti, 2013). The low bacterial count or dehydrogenase activity under high $\mathrm{N}$ fertilization rates consistent with results in arable crop soils of heavy N fertilization (Shen et al., 2010; Sun et al., 2015). On the other hand, due to their gradual decomposition kinetics, inputs of humates continuously provide nutrients which could be utilized by microbial communities and tend to act as slow-release biostimulants for microorganisms (Pukalchik et al., 2019). In addition, humic acid amendments affect the rhizodeposition of plants and concomitantly the structure of rhizosphere microbial communities (Sun et al., 2015) as well as in the presence of hardly bioavailable organic materials, and plants stimulate a more massive microbial activity (Bonkowski, 2004). 
TABLE 4. Biological paramters of the rhizosphere of lentil plants in response to mineral nitrogen, crude humates or PGPR application under calcareous soil

\begin{tabular}{|c|c|c|c|c|c|}
\hline \multirow{2}{*}{\multicolumn{2}{|c|}{ Treatment }} & \multicolumn{2}{|c|}{ Season 2018/19 } & \multicolumn{2}{|c|}{ Season 2019/20 } \\
\hline & & $\begin{array}{l}\text { Total bacteria count } \\
\qquad\left(\times \mathbf{1 0}^{7}\right)\end{array}$ & $\begin{array}{l}\text { Dehydrogenase activity } \\
\text { ( } \mu \mathrm{g} \text { TPF } \mathrm{g}^{-1} \text { dry soil/h) }\end{array}$ & $\begin{array}{l}\text { Total bacteria count } \\
\qquad\left(\times \mathbf{1 0}^{7}\right)\end{array}$ & $\begin{array}{l}\text { Dehydrogenase activity } \\
\left.\text { ( } \mu \mathrm{g} \text { TPF } \mathrm{g}^{-1} \text { dry soil } / \mathrm{h}\right)\end{array}$ \\
\hline \multicolumn{6}{|c|}{ Means of cultivars ( $\mathrm{V}$ ) } \\
\hline \multicolumn{2}{|c|}{ Giza 9} & 2.73 & 52.79 & 3.10 & 55.98 \\
\hline \multicolumn{2}{|c|}{ Sinai 1} & 2.22 & 43.02 & 2.79 & 52.46 \\
\hline \multicolumn{2}{|c|}{$\operatorname{LSD}(p=0.05)$} & - & ns & - & ns \\
\hline \multicolumn{6}{|c|}{ Means of fertilizers $(T)$} \\
\hline \multicolumn{2}{|l|}{$\mathrm{T} 1$} & 2.08 & 40.37 & 2.53 & 47.69 \\
\hline \multicolumn{2}{|l|}{$\mathrm{T} 2$} & 1.59 & 30.77 & 2.06 & 39.89 \\
\hline \multicolumn{2}{|l|}{$\mathrm{T} 3$} & 1.93 & 37.86 & 2.44 & 49.53 \\
\hline \multicolumn{2}{|l|}{$\mathrm{T} 4$} & 2.55 & 48.67 & 2.60 & 50.96 \\
\hline \multicolumn{2}{|l|}{ T5 } & 3.25 & 62.53 & 3.98 & 64.32 \\
\hline \multicolumn{2}{|l|}{ T6 } & 3.47 & 67.22 & 4.05 & 72.95 \\
\hline \multicolumn{2}{|c|}{$\operatorname{LSD}(\mathrm{p}=0.05)$} & - & 4.37 & - & 7.93 \\
\hline \multicolumn{6}{|c|}{ Interaction effect $(V \times T)$} \\
\hline \multirow{6}{*}{$\begin{array}{l}\text { Giza } \\
9\end{array}$} & $\mathrm{~T} 1$ & 2.3 & 44.61 & 2.33 & 45.98 \\
\hline & $\mathrm{T} 2$ & 1.7 & 32.74 & 1.80 & 35.20 \\
\hline & $\mathrm{T} 3$ & 2.4 & 47.20 & 2.95 & 57.07 \\
\hline & $\mathrm{T} 4$ & 2.9 & 55.14 & 2.94 & 57.41 \\
\hline & $\mathrm{T} 5$ & 3.3 & 63.34 & 4.16 & 64.87 \\
\hline & T6 & 3.8 & 73.72 & 4.41 & 75.38 \\
\hline \multirow{6}{*}{$\begin{array}{l}\text { Sinai } \\
1\end{array}$} & $\mathrm{~T} 1$ & 1.86 & 36.13 & 2.73 & 38.31 \\
\hline & $\mathrm{T} 2$ & 1.49 & 28.80 & 2.31 & 44.57 \\
\hline & $\mathrm{T} 3$ & 1.45 & 28.51 & 1.94 & 53.08 \\
\hline & $\mathrm{T} 4$ & 2.20 & 42.20 & 2.25 & 44.51 \\
\hline & $\mathrm{T} 5$ & 3.19 & 61.73 & 3.79 & 63.76 \\
\hline & T6 & 3.15 & 60.73 & 3.68 & 70.53 \\
\hline \multicolumn{2}{|c|}{$\operatorname{LSD}(\mathrm{P}=0.05)$} & - & ns & - & $\mathrm{ns}$ \\
\hline
\end{tabular}

- ns: Not significant

Vegetative state

The plant morphological parameters are given in Table 5. With the exception the plant height and leaf area, the two cultivars of lentil showed significantly differences for other features in first seasons. However, Giza 9 cultivar was surpassed by 13.5 or $10.6,27.0$ or $30.8,21.5$ or 21.2 and 11.9 or $16.6 \%$ for plant height, shoot dry wt., root surface area and leaf area in the first or second season, respectively.

In general, the addition of high humates followed by a full dose of nitrogen recorded maximum values of the plant height, shoot dry wt. and leaf area. However, the PGPR significantly extended the root surface area by 165.8, 100 or $86.0 \%$ over the control, full $\mathrm{N}$ dose or $15 \mathrm{~kg}$ $\mathrm{N}$ dose in the first season, respectively. The corresponding increments in the second season were $151.0,88.5$ or $73.6 \%$, respectively.

According to dark green color index (DGCI), the plants significantly captured more greenness due to application of a full dose of nitrogen followed by high dose of humate (20L/fed.) with Giza 9 as compared with Sinai 1 cultivar which

Egypt. J. Agron. 43, No. 1 (2021) 
treated alike. The control treatment followed by application of $15 \mathrm{~kg} \mathrm{~N}$ dose appeared less green than other treatments in both cultivars during both seasons. The addition of full $\mathrm{N}$ dose with Giza 9 resulted in the greenness of Giza 9 and Sinai 1 by 64.3 and $122.0 \%$ or 91.8 and $81.2 \%$ over control in the first or second season, respectively.
The corresponding increments due to application of a high dose of humate were 48.0 and $120.7 \%$ or 56.8 and $83.5 \%$, respectively. Meanwhile, the PGPR inoculation recorded 38.3 and $90.2 \%$ or 47.7 or $37.0 \%$ over control for Giza 9 and Sinai 1 in the first or second season, respectively.

TABLE 5. Some morphological features of lentil plants at the vegetative stage in response to mineral nitrogen, crude humates or PGPR application under calcareous soil

\begin{tabular}{|c|c|c|c|c|c|c|c|c|c|c|c|}
\hline \multirow{2}{*}{\multicolumn{2}{|c|}{ Treatment }} & \multicolumn{5}{|c|}{ Season $(2018 / 19)$} & \multicolumn{5}{|c|}{ Season $(2019 / 20)$} \\
\hline & & \multirow[t]{2}{*}{$\begin{array}{l}\text { Plant } \\
\text { height } \\
(\mathrm{cm})\end{array}$} & \multirow[t]{2}{*}{$\begin{array}{l}\text { Shoot } \\
\text { dry wt. } \\
\text { (g/plant) }\end{array}$} & \multirow[t]{2}{*}{$\begin{array}{c}\text { Root } \\
\text { surface } \\
\text { area }\left(\mathbf{c m}^{2}\right)\end{array}$} & \multirow[t]{2}{*}{$\begin{array}{l}\text { Leaf area } \\
\qquad\left(\mathrm{cm}^{2}\right)\end{array}$} & \multirow[t]{2}{*}{ DGCI } & \multirow[t]{2}{*}{$\begin{array}{c}\text { Plant } \\
\text { height } \\
(\mathrm{cm})\end{array}$} & \multirow[t]{2}{*}{$\begin{array}{c}\text { Shoot } \\
\text { dry } \\
\text { wt. } \\
\text { (g/plant) }\end{array}$} & \multirow[t]{2}{*}{$\begin{array}{c}\text { Root } \\
\text { surface } \\
\text { area } \\
\left(\mathbf{c m}^{2}\right)\end{array}$} & \multirow[t]{2}{*}{$\begin{array}{l}\text { Leaf area } \\
\qquad\left(\mathrm{cm}^{2}\right)\end{array}$} & \multirow[t]{2}{*}{ DGCI } \\
\hline & & & & & & & & & & & \\
\hline Giza 9 & & 28.17 & 2.70 & 2.94 & 3.47 & 0.518 & 28.44 & 2.80 & 2.92 & 3.58 & 0.519 \\
\hline Sinai 1 & & 24.83 & 2.11 & 2.42 & 3.10 & 0.456 & 25.72 & 2.14 & 2.41 & 3.07 & 0.464 \\
\hline $\mathrm{LSD}_{0.05}$ & & ns & 0.21 & 0.42 & ns & 0.0312 & 1.26 & 0.14 & 0.35 & 0.188 & 0.0074 \\
\hline \multicolumn{12}{|c|}{ Means of fertilizers (T) } \\
\hline $\mathrm{T} 1$ & & 23.33 & 1.70 & 1.55 & 2.39 & 0.314 & 23.67 & 1.71 & 1.57 & 2.37 & 0.328 \\
\hline $\mathrm{T} 2$ & & 25.67 & 2.49 & 1.99 & 3.68 & 0.586 & 28.00 & 2.78 & 2.09 & 3.84 & 0.612 \\
\hline $\mathrm{T} 3$ & & 26.83 & 2.26 & 2.14 & 3.22 & 0.427 & 24.33 & 2.32 & 2.27 & 3.16 & 0.446 \\
\hline $\mathrm{T} 4$ & & 26.00 & 2.29 & 3.98 & 3.29 & 0.498 & 27.33 & 2.32 & 3.94 & 3.36 & 0.468 \\
\hline T5 & & 27.50 & 2.74 & 3.64 & 3.43 & 0.546 & 30.17 & 2.63 & 3.38 & 3.51 & 0.542 \\
\hline T6 & & 29.67 & 2.95 & 2.78 & 3.71 & 0.554 & 29.00 & 3.04 & 2.72 & 3.74 & 0.554 \\
\hline $\operatorname{LSD}(\mathrm{P}=$ & $.05)$ & 2.03 & 0.28 & 0.38 & 0.31 & 0.0298 & 2.30 & 0.23 & 0.38 & 0.31 & 0.0428 \\
\hline \multicolumn{12}{|c|}{ Interaction effect $(V \times T)$} \\
\hline \multirow{6}{*}{ Giza 9} & $\mathrm{~T} 1$ & 24.00 & 2.03 & 1.79 & 2.67 & 0.381 & 25.00 & 2.06 & 2.05 & 2.65 & 0.352 \\
\hline & $\mathrm{T} 2$ & 27.67 & 2.80 & 2.14 & 3.98 & 0.626 & 28.00 & 3.26 & 2.25 & 4.18 & 0.675 \\
\hline & $\mathrm{T} 3$ & 27.67 & 2.52 & 2.53 & 3.40 & 0.480 & 25.33 & 2.67 & 2.53 & 3.38 & 0.457 \\
\hline & $\mathrm{T} 4$ & 27.33 & 2.59 & 4.54 & 3.30 & 0.527 & 28.00 & 2.59 & 4.21 & 3.65 & 0.520 \\
\hline & T5 & 29.33 & 3.18 & 3.59 & 3.57 & 0.532 & 32.33 & 3.01 & 3.59 & 3.71 & 0.555 \\
\hline & T6 & 33.00 & 3.08 & 3.06 & 3.93 & 0.564 & 32.00 & 3.22 & 2.87 & 3.93 & 0.552 \\
\hline \multirow{6}{*}{ Sinai 1} & $\mathrm{~T} 1$ & 22.67 & 1.37 & 1.32 & 2.10 & 0.246 & 22.33 & 1.37 & 1.10 & 2.08 & 0.303 \\
\hline & $\mathrm{T} 2$ & 23.67 & 2.18 & 1.84 & 3.38 & 0.546 & 28.00 & 2.31 & 1.92 & 3.50 & 0.549 \\
\hline & $\mathrm{T} 3$ & 26.00 & 2.00 & 1.75 & 3.04 & 0.374 & 23.33 & 1.98 & 2.01 & 2.93 & 0.435 \\
\hline & $\mathrm{T} 4$ & 24.67 & 1.99 & 3.42 & 3.28 & 0.468 & 26.67 & 2.05 & 3.68 & 3.06 & 0.415 \\
\hline & T5 & 25.67 & 2.30 & 3.68 & 3.29 & 0.560 & 28.00 & 2.25 & 3.16 & 3.31 & 0.528 \\
\hline & T6 & 26.33 & 2.81 & 2.51 & 3.49 & 0.543 & 26.00 & 2.87 & 2.57 & 3.55 & 0.556 \\
\hline \multicolumn{2}{|c|}{$\begin{array}{l}\text { LSD } \\
(\mathrm{P}=0.05)\end{array}$} & ns & ns & ns & ns & 0.0421 & ns & $\mathrm{ns}$ & $\mathrm{ns}$ & ns & 0.061 \\
\hline
\end{tabular}

- ns: Not significant 
The obtained results are in agreement with Kahraman (2016) and Abdel-Baky et al. (2019) whose revealed the promotion of fulvic or humic acids on the vegetative growth and dry matter production of faba bean cultivars, at the three stages of growth, and cowpea cultivars by increasing the development of shoots and roots, increasing leaf area and chlorophyll. Although the stimulation effects of humate on growth parameters of plant are not fully clear, there are some theories which potentially work together including the beneficial physical, biological and chemical actions on soils and could increase plant growth (Chen \& Aviad, 1990; Tufail et al., 2014). The positive effect of PGPR or humate, which stimulate the microbial activity in the rhizosphere (Table 4), on root surface area due to PGPR can produce a wide range of phytohormones (Vacheron et al., 2013; Chen et al., 2017).

The Dark Green Color Index (DGCI) is a technology that may give an appropriate way to assess plant $\mathrm{N}$ status is the intensity of green color from digital images of leaves (Karcher \& Richardson, 2003). So, the increases in DGCI values may reflect the nutrition improvement of plants due to application of a high dose of nitrogen or humate (Gazola et al., 2016; Rhezali \& Lahlali, 2017). Humate could potentially affect plant physiology leading to increase in the content of chlorophyll pigment (Ameri \& Tehranifar, 2013) which gives a plant its green color .

\section{The nodulation status}

The nodulation status, as affected by different treatments is shown in Table 6 , based on the number and dry mass of nodules per plant. The data reveal non-significant differences between different cultivars in the first season. However, in the second season, Giza 9 cultivar significantly surpassed Sinai 1 nodules number with nonsignificant variation in their dry weight. The nodulation capacity usually related to the genetic potential and other intrinsic characteristics of each cultivar (Zuffo et al., 2018). The results are in agreement with Badawi et al. (2014). They found that Giza 9 variety significantly surpassed the new released early maturing variety (Sinai 1) by 12.5 and $12.0 \%$ in the number of nodules and dry weight of nodules by 9.9 and $5.6 \%$ in both growing seasons.

Regarding the effect of fertilizers on the nodulation status, the application of a full dose of mineral nitrogen to some extent retarded against humate or PGPR, which showed a boosted action. In this concern, Eardly et al. (1985) and David \& Khan (2001) documented that larger or continued application of nitrogen in the soil reduced nodulation and the activity of rhizobia which in turn resulted in less rhizobial infection to plant roots and less number of nodules per plant. Root nodulating legumes prefer the uptake of mineral nitrogen for energetical reasons and consequently reduce the rate of symbiotic $\mathrm{N}_{2}$-fixation (Becker et al., 1986).

The humate addition surpassed the coinoculation effect of Rhizobium with PGPR in both seasons. The maximum values of number and mass of nodules were recorded by a high rate of humate treatments. The high dose of humate increased number and mass of nodules by 31.0 to $31.9 \%$ and 31.1 to $31.4 \%$, respectively. The corresponding increments due to PGPR were 18.3 to $19 \%$ and 18.5 to $19.3 \%$, respectively, in both seasons. The stimulation effect of PGPR or humates may be due to stimulation of root growth, carbohydrate overproduction, hormonal like effect within the plant as well as increase soil microorganisms (Coskan \& Dogan, 2011; Korir et al., 2017). These findings confirm the results of Gaur \& Bhardwaj (1971), who found that the effectiveness of Rhizobium as legume inoculant was appreciably increased with the application of sodium humate which included stimulation of growth and activities of the useful native and introduced microflora of the rhizosphere of crop plants. Also, Tan \& Tantiwiramanond (1983) noticed a positive correlation between increases in nodules and humate concentrations of soybean, peanut and clover grown in sand cultures containing 0 to 800 ppm of fulvic acid (FA) or humic acid (HA).

\section{Nutrition status}

The nutrition status due to application of mineral nitrogen, humate or PGPR into calcareous soil grown with two different cultivars of lentil during two seasons is represented by NPK in the shoot in Table 7. Depending on the grown cultivar, the plants differentially responded to various fertilizer treatments in terms of nitrogen or potassium contents especially in the second season. Humate, as well as full dose of mineral nitrogen, significantly increased uptake of nitrogen or potassium, with the superiority of Giza 9 over Sinai 1 cultivar, comparing with other treatments. However, a high dose of humate significantly 
raised the nitrogen uptake (13.5 or $21.7 \%$ over lower dose of humate) by Sinai 1 than Giza 9, which recorded non-significant variation.

On the other hand, the phosphorus content affected due to fertilizers treatments without depending on the cultivar during both seasons. The humate addition significantly increased the phosphorus uptake over absolute mineral nitrogen treatment by 13.6 and $11.9 \%$ in the first and second season, respectively. Co-inoculation with PGPR and Rhizobium (T4) resulted in an improvement in the nutrient uptake against control (T1) or Rhizobium + activation dose (T3) treatment.

The increase of nutrients uptake due to mineral nitrogen fertilization previously proven by Pasley et al. (2019). However, an interaction of humate with plasma membrane $\mathrm{H}^{+}$-ATPase may explain its role for the incorporation of nitrate uptake (Pinton et al., 1999). Also, humic acid can induce the metabolism of carbon and nitrogen metabolism and incite some enzymes related to nitrogen assimilation pathways such as Glutamate dehydrogenase, nitrate reductase and glutamine synthetase (Hernandez et al., 2015). Furthermore, humic acid act to stimulate biological activity (Table 4) leading to the enhancement of water solvable $P$ and total N content (Busato et al., 2012). The results in harmony with Asik et al. (2009) who stated that humic substances can ameliorate negative soil properties and improve the plant growth and uptake of nutrients. The role of PGPR may be due to their influence on root and their vital role in the nutrient cycle (Pérez-Montaño et al., 2014).

TABLE 6. Nodulation paramters of lentil plants in response to mineral nitrogen, crude humates or PGPR application under calcareous soil

\begin{tabular}{|c|c|c|c|c|c|}
\hline \multirow{2}{*}{\multicolumn{2}{|c|}{ Treatment }} & \multicolumn{2}{|c|}{ Season 2018/19 } & \multicolumn{2}{|c|}{ Season 2019/20 } \\
\hline & & \multirow[t]{2}{*}{$\begin{array}{c}\text { Nodules } \\
\text { (Nos./plant) }\end{array}$} & \multirow{2}{*}{$\begin{array}{c}\text { Nodules dry wt. } \\
\text { (mg/plant) }\end{array}$} & \multirow[t]{2}{*}{$\begin{array}{c}\text { Nodules } \\
\text { (Nos./plant) } \\
\end{array}$} & \multirow[t]{2}{*}{$\begin{array}{c}\text { Nodules dry wt. } \\
\text { (mg/plant) }\end{array}$} \\
\hline \multicolumn{2}{|c|}{ Means of cultivars (V) } & & & & \\
\hline Giza 9 & & 7.39 & 50.69 & 8.06 & 51.21 \\
\hline Sinai 1 & & 6.50 & 44.51 & 6.94 & 45.02 \\
\hline $\operatorname{LSD}(\mathrm{P}=$ & & ns & ns & 0.96 & ns \\
\hline \multicolumn{6}{|c|}{ Means of fertilizers (T) } \\
\hline $\mathrm{T} 1$ & & 3.83 & 25.97 & 4.67 & 26.47 \\
\hline $\mathrm{T} 2$ & & 4.67 & 31.77 & 5.33 & 32.20 \\
\hline $\mathrm{T} 3$ & & 7.00 & 47.99 & 7.33 & 48.58 \\
\hline $\mathrm{T} 4$ & & 8.33 & 57.25 & 8.67 & 57.55 \\
\hline T5 & & 8.67 & 59.58 & 9.33 & 60.21 \\
\hline $\mathrm{T} 6$ & & 9.17 & 63.05 & 9.67 & 63.67 \\
\hline $\operatorname{LSD}(\mathrm{P}=$ & 05) & 0.88 & 6.08 & 0.78 & 6.09 \\
\hline \multicolumn{6}{|c|}{ Interaction effect $(V \times T)$} \\
\hline \multirow{6}{*}{ Giza 9} & $\mathrm{~T} 1$ & 4.67 & 31.77 & 5.33 & 32.10 \\
\hline & $\mathrm{T} 2$ & 5.00 & 34.09 & 6.00 & 34.55 \\
\hline & $\mathrm{T} 3$ & 7.33 & 50.31 & 7.67 & 51.04 \\
\hline & $\mathrm{T} 4$ & 8.67 & 59.57 & 9.67 & 60.02 \\
\hline & $\mathrm{T} 5$ & 9.67 & 66.52 & 10.00 & 67.02 \\
\hline & $\mathrm{T} 6$ & 9.00 & 61.89 & 9.67 & 62.54 \\
\hline \multirow{6}{*}{ Sinai 1} & $\mathrm{~T} 1$ & 3.00 & 20.18 & 4.00 & 20.84 \\
\hline & $\mathrm{T} 2$ & 4.33 & 29.45 & 4.67 & 29.86 \\
\hline & $\mathrm{T} 3$ & 6.67 & 45.67 & 7.00 & 46.11 \\
\hline & $\mathrm{T} 4$ & 8.00 & 54.94 & 7.67 & 55.09 \\
\hline & $\mathrm{T} 5$ & 7.67 & 52.63 & 8.67 & 53.40 \\
\hline & T6 & 9.33 & 64.20 & 9.67 & 64.80 \\
\hline \multicolumn{2}{|c|}{$\operatorname{LSD}(\mathrm{P}=0.05)$} & $\mathrm{ns}$ & ns & $\mathrm{ns}$ & ns \\
\hline
\end{tabular}

- ns: Not significant 
TABLE 7. Nutrient uptake by lentil plants in response to mineral nitrogen, crude humates or PGPR application under calcareous soil

\begin{tabular}{|c|c|c|c|c|c|c|c|}
\hline \multirow{2}{*}{\multicolumn{2}{|c|}{ Treatment }} & \multicolumn{3}{|c|}{ Season $(2018 / 19)$} & \multicolumn{3}{|c|}{ Season $(2019 / 20)$} \\
\hline & & \multirow[t]{2}{*}{$\begin{array}{c}\mathrm{N} \\
\text { (mg/plant) }\end{array}$} & \multirow{2}{*}{$\begin{array}{r}\begin{array}{c}\text { P } \\
\text { (mg/plant) }\end{array} \\
M \\
\end{array}$} & \multirow{2}{*}{$\begin{array}{c}\text { K } \\
\text { (mg/plant) }\end{array}$} & \multirow{2}{*}{$\begin{array}{c}\mathrm{N} \\
\text { (mg/plant) }\end{array}$} & \multirow[t]{2}{*}{$\begin{array}{c}\mathbf{P} \\
\text { (mg/plant) }\end{array}$} & \multirow[t]{2}{*}{$\begin{array}{c}\mathrm{K} \\
\text { (mg/plant) }\end{array}$} \\
\hline \multicolumn{2}{|c|}{ Means of cultivars ( $V$ ) } & & & & & & \\
\hline Giza 9 & & 61.84 & 19.35 & 72.34 & 64.71 & 20.00 & 79.65 \\
\hline Sinai 1 & & 52.10 & 18.10 & 63.99 & 53.62 & 18.57 & 65.62 \\
\hline $\operatorname{LSD}(\mathrm{P}=$ & $.05)$ & 3.69 & ns & 4.04 & 1.59 & ns & 5.99 \\
\hline \multicolumn{8}{|c|}{ Means of fertilizers (T) } \\
\hline $\mathrm{T} 1$ & & 37.94 & 13.92 & 50.77 & 39.55 & 14.50 & 49.78 \\
\hline $\mathrm{T} 2$ & & 61.44 & 19.66 & 76.50 & 65.37 & 20.08 & 81.73 \\
\hline $\mathrm{T} 3$ & & 54.96 & 16.60 & 61.90 & 56.22 & 17.25 & 70.27 \\
\hline $\mathrm{T} 4$ & & 56.59 & 18.93 & 68.79 & 57.26 & 19.41 & 72.22 \\
\hline T5 & & 63.81 & 20.92 & 71.99 & 64.87 & 22.00 & 80.12 \\
\hline T6 & & 67.09 & 22.34 & 79.04 & 71.72 & 22.46 & 81.67 \\
\hline $\operatorname{LSD}(\mathrm{P}=$ & $.05)$ & 2.60 & 1.86 & 6.18 & 3.98 & 1.89 & 6.39 \\
\hline \multicolumn{8}{|c|}{ Interaction effect $(\mathrm{V} \times \mathrm{T})$} \\
\hline \multirow{6}{*}{ Giza 9} & $\mathrm{~T} 1$ & 39.57 & 14.48 & 53.71 & 41.42 & 14.97 & 60.81 \\
\hline & $\mathrm{T} 2$ & 66.40 & 20.96 & 83.35 & 72.55 & 21.10 & 87.35 \\
\hline & $\mathrm{T} 3$ & 59.76 & 17.25 & 62.67 & 63.27 & 18.04 & 80.95 \\
\hline & $\mathrm{T} 4$ & 62.06 & 19.13 & 74.86 & 64.49 & 19.98 & 81.02 \\
\hline & T5 & 72.12 & 21.63 & 76.51 & 72.61 & 22.88 & 82.81 \\
\hline & T6 & 71.16 & 22.64 & 82.94 & 73.91 & 23.02 & 84.94 \\
\hline \multirow{6}{*}{$\begin{array}{l}\text { Sinai } \\
1\end{array}$} & $\mathrm{~T} 1$ & 36.31 & 13.36 & 47.83 & 37.68 & 14.02 & 38.75 \\
\hline & $\mathrm{T} 2$ & 56.49 & 18.35 & 69.65 & 58.19 & 19.07 & 76.10 \\
\hline & $\mathrm{T} 3$ & 50.16 & 15.94 & 61.13 & 49.17 & 16.46 & 59.59 \\
\hline & $\mathrm{T} 4$ & 51.12 & 18.73 & 62.71 & 50.03 & 18.85 & 63.42 \\
\hline & T5 & 55.51 & 20.21 & 67.46 & 57.13 & 21.12 & 77.43 \\
\hline & T6 & 63.01 & 22.04 & 75.14 & 69.52 & 21.90 & 78.40 \\
\hline \multicolumn{2}{|c|}{$\operatorname{LSD}(\mathrm{P}=0.05)$} & 3.67 & $\mathrm{~ns}$ & $\mathrm{~ns}$ & 5.62 & $\mathrm{~ns}$ & 9.04 \\
\hline
\end{tabular}

- ns: Not significant

\section{Reproductive stage}

The reproductive stage of lentil growth, begins when the plant begins to flower at any node, was assessed based on some traits, which are illustrated in Table 8, in response to the studied treatments.

With the exception of branches number, all traits were significantly influenced by fertilizer treatments depending on the grown cultivar. Giza 9 was taller than Sinai 1 plants where treated with a high dose of humate $(20 \mathrm{~L} / \mathrm{fed}$.) to be 48.7 or $50.0 \mathrm{~cm}$ in the first or second season, respectively. The taken days to 50 or $90 \%$ flowering were less in Sinai 1 than that in Giza 9 with a high dose of humate which followed with a full dose of nitrogen during both growing seasons. On the other hand, number of branches/ plant depended only on the type of fertilization with non-significant differences due to cultivar. The full dose of nitrogen followed by humate maximized the branch numbers as compared with other treatments. Application of PGPR did not significantly increase the branches/plant when co-inoculated with Rhizobium.

The variation in flowering among two different cultivars might be due to their genetic variation and adaptability to the climatic conditions of the study area. In this concern, Aloran (2004) and Rizk et al. (2011) confirmed that Sinai 1 cultivar was superior on early maturation character, while Giza 9 variety surpassed Sinai 1 in most 
vegetative and yield characters. Regarding the humate effect, it might be due to enhanced chlorophyll content in leaves and/or boost up the uptake of nutrients from the soil which played an essential role in early flowering (Haider et al., 2017). Likewise, the auxin-like activity of humate act to stimulate the cell division and cell elongation and in turn, the number of branches (Dawood et al., 2019).
Seeds yield and its components

The data in Table 9 represent seeds yield components of two different lentil cultivars in response to mineral nitrogen, crude humates or PGPR application under calcareous soil. The response of lentil to various fertilization practices showed a significant variation due to grown cultivar with all yield components except the 1000 -seeds weight.

TABLE 8. Lentil plant parameters at reproductive stage in response to mineral nitrogen, crude humates or PGPR application under calcareous soil

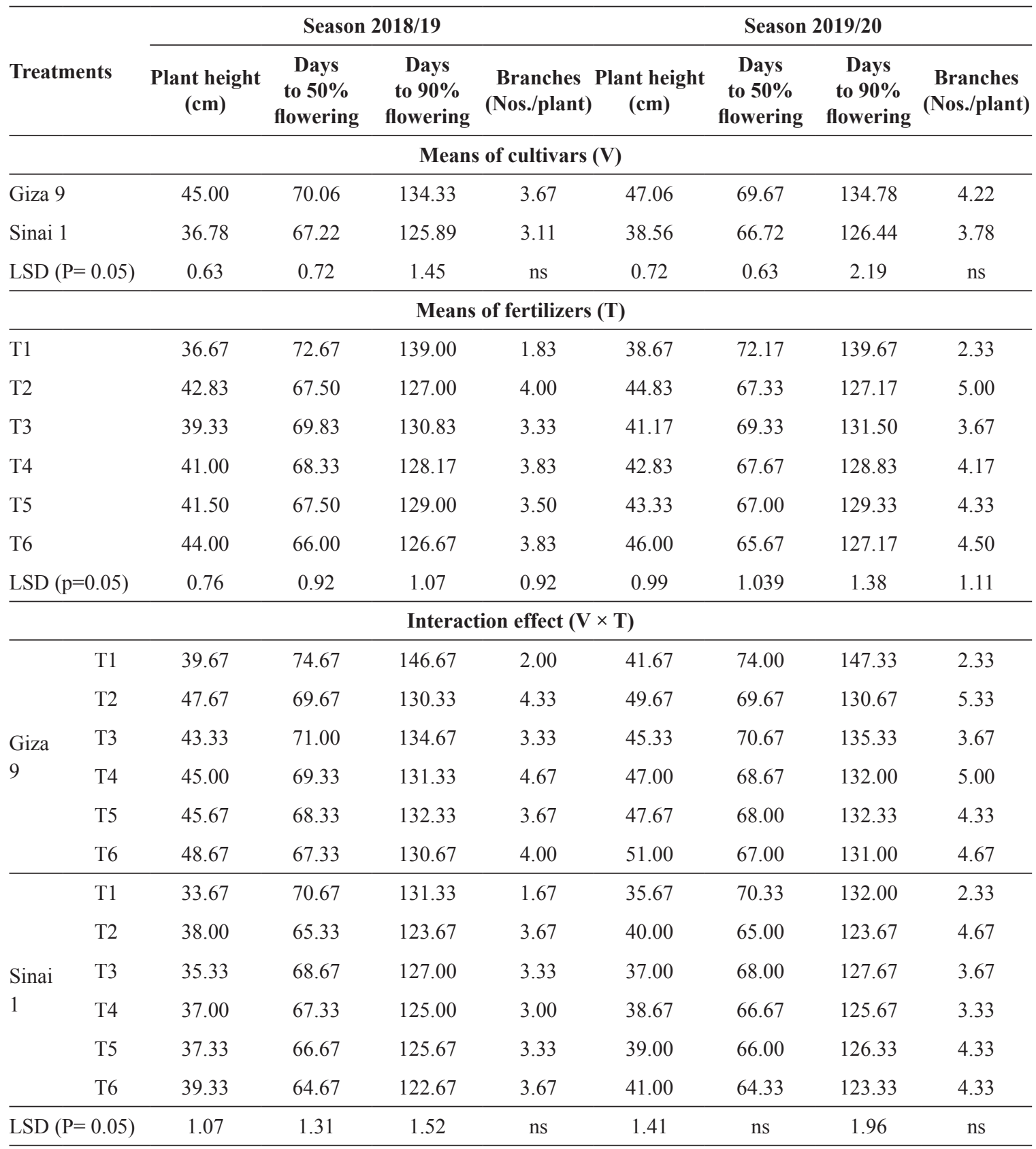

- ns: Not significant 
TABLE 9. Seeds yield and its components of lentil cultivars as influenced by mineral nitrogen, crude humates or PGPR application under calcareous soil

\begin{tabular}{|c|c|c|c|c|c|c|c|c|c|c|c|}
\hline \multirow{2}{*}{\multicolumn{2}{|c|}{ Treatments }} & \multicolumn{5}{|c|}{ Season $(2018 / 19)$} & \multicolumn{5}{|c|}{ Season $(2019 / 20)$} \\
\hline & & $\begin{array}{l}\text { Pods } \\
\text { (Nos./ } \\
\text { plant) }\end{array}$ & $\begin{array}{l}\text { Seeds } \\
\text { (Nos./ } \\
\text { plant) }\end{array}$ & $\begin{array}{c}\text { Seeds } \\
\text { yield (g/ } \\
\text { plant) }\end{array}$ & $\begin{array}{c}\text { 1000-seeds } \\
\text { wt. (g) }\end{array}$ & $\begin{array}{c}\text { Seed* } \\
\text { yield } \\
\text { (ardab/ } \\
\text { fed.) }\end{array}$ & $\begin{array}{l}\text { Pods } \\
\text { (Nos./ } \\
\text { plant) }\end{array}$ & $\begin{array}{l}\text { Seeds } \\
\text { (Nos./ } \\
\text { plant) }\end{array}$ & $\begin{array}{l}\text { Seeds } \\
\text { yield/ } \\
\text { plant }\end{array}$ & $\begin{array}{c}\text { 1000-seeds } \\
\text { wt. (g) }\end{array}$ & $\begin{array}{c}\text { Seed } \\
\text { yield } \\
\text { (ardab/ } \\
\text { fed.) }\end{array}$ \\
\hline \multicolumn{12}{|c|}{ Means of cultivars ( $V$ ) } \\
\hline \multicolumn{2}{|c|}{ Giza 9} & 70.67 & 100.83 & 2.15 & 23.67 & 4.73 & 72.72 & 103.11 & 4.78 & 24.18 & 4.79 \\
\hline \multicolumn{2}{|c|}{ Sinai 1} & 38.33 & 59.17 & 1.79 & 34.33 & 3.93 & 40.11 & 61.00 & 1.85 & 34.78 & 3.98 \\
\hline \multicolumn{2}{|c|}{$\begin{array}{l}\text { LSD } \\
(\mathrm{P}=0.05)\end{array}$} & 14.42 & 17.63 & 0.04 & 3.29 & 0.02 & 14.55 & 17.81 & 0.02 & 3.44 & 0.02 \\
\hline \multicolumn{12}{|c|}{ Means of fertilizers (T) } \\
\hline \multicolumn{2}{|l|}{$\mathrm{T} 1$} & 27.50 & 40.50 & 1.01 & 18.33 & 2.24 & 29.33 & 42.17 & 1.73 & 18.71 & 2.29 \\
\hline \multicolumn{2}{|l|}{$\mathrm{T} 2$} & 64.50 & 95.50 & 2.27 & 32.00 & 4.99 & 66.50 & 97.83 & 3.83 & 32.34 & 5.05 \\
\hline \multicolumn{2}{|l|}{ T3 } & 49.50 & 69.00 & 1.77 & 28.50 & 3.90 & 51.67 & 71.00 & 3.03 & 29.01 & 3.94 \\
\hline \multicolumn{2}{|l|}{$\mathrm{T} 4$} & 57.00 & 78.50 & 2.15 & 30.17 & 4.69 & 58.67 & 80.33 & 3.58 & 30.99 & 4.75 \\
\hline \multicolumn{2}{|l|}{ T5 } & 59.50 & 92.00 & 2.19 & 31.00 & 4.80 & 61.50 & 94.17 & 3.68 & 31.34 & 4.86 \\
\hline \multicolumn{2}{|l|}{ T6 } & 69.00 & 104.50 & 2.45 & 34.00 & 5.36 & 70.83 & 106.83 & 4.05 & 34.46 & 5.41 \\
\hline \multicolumn{2}{|c|}{$\begin{array}{l}\text { LSD } \\
(\mathrm{P}=0.05)\end{array}$} & 3.25 & 4.70 & 0.041 & 2.89 & 0.01 & 3.21 & 4.81 & 0.03 & 2.87 & 0.04 \\
\hline \multicolumn{12}{|c|}{ Interaction effect $(\mathrm{V} \times \mathrm{T})$} \\
\hline \multirow{6}{*}{$\begin{array}{l}\text { Giza } \\
9\end{array}$} & $\mathrm{~T} 1$ & 33.00 & 47.00 & 1.07 & 15.67 & 2.41 & 35.00 & 49.00 & 2.44 & 16.13 & 2.45 \\
\hline & $\mathrm{T} 2$ & 82.00 & 120.00 & 2.49 & 26.00 & 5.47 & 84.00 & 122.67 & 5.53 & 26.29 & 5.53 \\
\hline & $\mathrm{T} 3$ & 68.00 & 92.00 & 1.99 & 22.00 & 4.38 & 70.33 & 94.00 & 4.44 & 22.61 & 4.46 \\
\hline & $\mathrm{T} 4$ & 76.00 & 100.00 & 2.34 & 24.33 & 5.12 & 78.00 & 102.00 & 5.16 & 25.07 & 5.17 \\
\hline & $\mathrm{T} 5$ & 79.00 & 117.00 & 2.41 & 25.00 & 5.27 & 81.00 & 119.33 & 5.32 & 25.46 & 5.34 \\
\hline & T6 & 86.00 & 129.00 & 2.62 & 29.00 & 5.73 & 88.00 & 131.67 & 5.80 & 29.51 & 5.78 \\
\hline \multirow{6}{*}{$\begin{array}{l}\text { Sinai } \\
1\end{array}$} & $\mathrm{~T} 1$ & 22.00 & 34.00 & 0.95 & 21.00 & 2.07 & 23.67 & 35.33 & 1.01 & 21.29 & 2.13 \\
\hline & $\mathrm{T} 2$ & 47.00 & 71.00 & 2.06 & 38.00 & 4.51 & 49.00 & 73.00 & 2.13 & 38.40 & 4.56 \\
\hline & $\mathrm{T} 3$ & 31.00 & 46.00 & 1.56 & 35.00 & 3.41 & 33.00 & 48.00 & 1.63 & 35.41 & 3.43 \\
\hline & $\mathrm{T} 4$ & 38.00 & 57.00 & 1.95 & 36.00 & 4.27 & 39.33 & 58.67 & 2.00 & 36.90 & 4.32 \\
\hline & $\mathrm{T} 5$ & 40.00 & 67.00 & 1.98 & 37.00 & 4.32 & 42.00 & 69.00 & 2.05 & 37.23 & 4.38 \\
\hline & T6 & 52.00 & 80.00 & 2.28 & 39.00 & 4.98 & 53.67 & 82.00 & 2.30 & 39.41 & 5.04 \\
\hline \multicolumn{2}{|c|}{$\begin{array}{l}\text { LSD } \\
(\mathrm{P}=0.05)\end{array}$} & 4.60 & 6.64 & 0.06 & ns & 0.01 & 4.55 & 6.80 & 0.05 & ns & 0.06 \\
\hline
\end{tabular}

*One ardab $=160$ kilogram. 1 hectare $=2.38$ feddan.

- ns: Not significant

The maximum values were recorded by Giza 9 cultivar fertilized with a high dose of humate (T6) followed by with full dose of nitrogen for pods and seeds number as well as seeds yield per plant during both grown seasons. However, the effect the co-inoculation with PGPR and Rhizobium (T4) increased the yield components compared to absolute control (T1) and treatment (T3) of individual Rhizobium + activation dose of nitrogen for the same parameters. The 1000-seeds weight increased by application of a high dose of humate followed by full dose of nitrogen for two cultivars with the superiority of Giza 9 cultivar. Regarding seed yield, the high dose of humate overweighted the full dose of nitrogen by 7.4 and $10.4 \%$ or 4.5 and $10.5 \%$ for Giza 9 and Saini 1 during first or second seasons, respectively. The co-inoculation with Rhizobium and PGPR (T4) recorded 16.9 and $25.2 \%$ or 15.9 and $26.0 \%$ increase over single inoculation with Rhizobium

Egypt. J. Agron. 43, No. 1 (2021) 
(T3) for Giza 9 and Siani 1 during first or second seasons, respectively.

Such increases in lentil yield and its components, due to humate or PGPR, might be attributed to the promotion of plant growth by the action of microorganisms in the rhizosphere which could positionally able to improve the symbiotic $\mathrm{N}_{2}$-fixation, availability of nutrients and/or plant growth factors. The results corroborate the findings of many previous studies on cowpea, soybean and chickpea (Abdelhamid et al., 2011; Kahraman, 2017; Tripura et al., 2017).

\section{Conclusion}

Based on 2 years experimentation, it may be concluded that the cultivation of Giza 9 cultivar with the application of crude humate at $20 \mathrm{~L} / \mathrm{fed}$. and Rhizobium inoculation is better option under calcareous soil for increased productivity and soil health of lentil. The humate act to stimulate the microbial activity in the plants rhizosphere as well as improve the nodulation and nutrient uptake of nutrients which intern lead to increments in yield and its components.

Acknowledgements: The authors express acknowledgement to Field Crops Research Institute (FCRI), Agricultural Research Center (ARC), for the facilities that gave rise to this article.

\section{References}

Abdel-Baky, Y.R., Abouziena, H.F., Amin, A.A., Rashad, E.-S.M., Abd El-Sttar, A.M. (2019) Improve quality and productivity of some faba bean cultivars with foliar application of fulvic acid. Bull. Natl. Res. Cent. 43, 1-11.

Abdelhamid, M.T., Selim, E.M., El-Ghamry, A.M. (2011) Integrated effects of bio and mineral fertilizers and humic substances on growth, yield and nutrient contents of fertigated cowpea (Vigna unguiculata L.) grown on sandy soils. J. Agron. 10, 34-39.

Aloran, A.A.S. (2004) Effect of nitrogen fertilization and Rhizobium inoculation on growth and yield of some lentil varieties. M.Sc. Thesis, Fac. Agric. Cairo Univ., Egypt.

Ameri, S.A., Tehranifar, A. (2013) Effect of humic acid on nutrient uptake and physiological characteristic Fragaria ananassa var: Camarosa. Acta Hortic. 6, 77-79.

Arancon, N.Q., Edwards, C.A., Lee, S., Byrne, R. (2006) Effects of humic acids from vermicomposts on plant growth. Eur. J. Soil Biol. 42, S65-S69.

Asik, B.B., Turan, M.A., Celik, H., Katkat, A.V. (2009) Effects of humic substances on plant growth and mineral nutrients uptake of wheat (Triticum durum cv. Salihli) under conditions of salinity. Asian $J$. Crop Sci. 1, 87-95.

Atlas, R.M. (2010) "Handbook of Microbiological Media". USA: CRC Press-Taylor and Francis Group.

Azcona, I., Pascual, I., Aguirreolea, J., Fuentes, M., García-Mina, José, M., Sánchez-Díaz, M. (2011) Growth and development of pepper are affected by humic substances derived from composted sludge. J. Plant Nutr. Soil Sci. 174, 916-924.

Badawi, F.S.F., Desoky, A.H., Selim, T. (2014) Response of two lentil varieties to bio-enriched compost tea. Nature and Science 12, 119 - 130.

Baker, B., Olszyk, D.M., Tingey, D. (1996) Digital image analysis to estimate leaf area. J. Plant Physiol. 148, 530-535.

Becker, M., Alazard, D., Ottow, J.C.G. (1986) Mineral nitrogen effect on nodulation and nitrogen fixation of the stem-nodulating legume Aeschynomene afraspera. Zeitschrift für Pflanzenernährung und Bodenkunde, 149, 485-491.

Black, C.A., Evans, D.D., Ensminger, L.E., White, J.L., Clark, F.E., Dinauer, R.C. (1956) "Methods of Soil Analysis. Part 2. Chemical and Microbiological Properties". Madison, Wisconsin, USA: Amer. Soc. Agron. Inc.

Bonkowski, M. (2004) Protozoa and plant growth: the microbial loop in soil revisited. New Phytol. 162, 617-631.

Borkar, S.G. (2015) "Microbes as Biofertilizers and Their Production Technology". New Delhi, India: Woodhead Publishing India Pvt Ltd.

Busato, J.G., Lima, L.S., Aguiar, N.O., Canellas, L.P., Olivares, F.L. (2012) Changes in labile phosphorus 
forms during maturation of vermicompost enriched with phosphorus-solubilizing and diazotrophic bacteria. Bioresour. Technol. 110, 390-395.

Casida, L.E.J. (1977) Microbial metabolic activity in soil as measured by dehydrogenase determinations. Appl. Environ. Microbiol. 34, 630-636.

Castro-Sowinski, S., Herschkovitz, Y., Okon, Y., Jurkevitch, E. (2007) Effects of inoculation with plant growth-promoting rhizobacteria on resident rhizosphere microorganisms. FEMS Microbiol. Lett. 276, 1-11.

Chapman, H.D., Pratt, P.F. (1961) "Methods of Analysis for Soils, Plants and Waters". Riversied, USA: Agriculture Plant University of California.

Chen, X., Kou, M., Tang, Z., Zhang, A., Li, H., Wei, M. (2017) Responses of root physiological characteristics and yield of sweet potato to humic acid urea fertilizer. PLoS One, 12, e0189715.

Chen, Y., Aviad, T. (1990) Effects of Humic Substances on Plant Growth. In: "Humic Substances in Soil and Crop Sciences: Selected Readings", P. MacCarthy, R.L. Malcolm and P.R. Bloom (Eds.), pp. 161-186. American Society of Agronomy, Inc. Soil Science Society of America, Inc., USA.

Coskan, A., Dogan, K. (2011) Effect of nitrate on nodulation and nitrogen fixation of soybean. In: "Soybean: Physiology and Biochemistry", H. ElShemy (Ed.), pp. 167-182. Cairo University, Cairo, Egypt.

David, J., Khan, K.S. (2001) Effect of nitrogen application on nodulation in inoculated chickpea (Cicer arietinum L.). J. Biol. Sci. 1, 87-89.

Dawood, M.G., Abdel-Baky, Y.R., El-Awadi, M.E.-S., Bakhoum, G.S. (2019) Enhancement quality and quantity of faba bean plants grown under sandy soil conditions by nicotinamide and/or humic acid application. Bull. Natl. Res. Cent. 43, 1-8.

Eardly, B.D., Hannaway, D.B., Bottomley, P.J. (1985) Nitrogen nutrition and yield of seedling alfalfa as affected by ammonium nitrate fertilization. Agron. J. 77, 57-62.

Elgabaly, M.M. (1973) Reclamation and management of the calcareous soils of Egypt. In: FAO Soils Bulletin 21, Calcareous soils: Report of the FAO/
UNDP Regional Seminar on Reclamation and Management of Calcareous Soils, E. Sacurna (Ed.), Cairo, Egypt, 27 Nov - 2 Dec 1972, FAO, Rome, pp. 123-127.

El-Zohri, M., Medhat, N., Saleh, F.M., El-Maraghy, S.S.M. (2017) Some biofertilizers relieved the stressful drawbacks of calcareous soil upon black seed (Nigella sativa 1.) through inhibiting stress markers and antioxidant enzymes with enhancing plant growth. Egypt. J. Bot. 57, 75 -92.

Etesami, H., Maheshwari, D.K. (2018) Use of plant growth promoting rhizobacteria (PGPRs) with multiple plant growth promoting traits in stress agriculture: Action mechanisms and future prospects. Ecotoxicol. Environ. Saf. 156, 225-246.

FAOSTAT (2019) Food and Agriculture Organization of the United Nations (FAO).

Gan, Y., Hamel, C., Kutcher, H.R., Poppy, L. (2016) Lentil enhances agroecosystem productivity with increased residual soil water and nitrogen. Renewable Agriculture and Food Systems 32, 319. 330.

Gangwar, M., Saini, P., Nikhanj, P., Kaur, S. (2017) Plant growth-promoting microbes (PGPM) as potential microbial bio-agents for eco-friendly agriculture. In: "Advances in Soil Microbiology: Recent Trends and Future Prospects: Volume 2: Soil-Microbe-Plant Interaction", T.K. Adhya, B.B. Mishra, K. Annapurna, D.K. Verma and U. Kumar (Eds.), pp. 37-55, Springer Singapore, Singapore.

Gaur, A.C., Bhardwaj, K.K.R. (1971) Influence of sodium humate on the crop plants inoculated with bacteria of agricultural importance. Plant Soil, 35, 613-621.

Gazola, R.P.D., Buzetti, S., Gazola, R.d.N., Castilho, R.M.M.d., Teixeira Filho, M.C.M., Celestrino, T.d.S., Dupas, E. (2016) Nitrogen dose and type of herbicide used for growth regulation on the green coloration intensity of Emerald grass. Cienc. Rural, 46, 984-990.

Gouda, S., Kerry, R.G., Das, G., Paramithiotis, S., Shin, H.S., Patra, J.K. (2018) Revitalization of plant growth promoting rhizobacteria for sustainable development in agriculture. Microbiol. Res. 206, 131-140.

Egypt. J. Agron. 43, No. 1 (2021) 
Grimont, F., Grimont, P.A.D. (2006) The genus Serratia. In: "Prokaryotes", M. Dworkin, S. Falkow, E. Rosenberg, K.H. Schleifer and E. Stackebrandt (Eds.), pp. 219-244. Springer-Verlag New York, USA.

Haider, N., Alam, M., Khan, A., Haider, W., Hussain, S., Zeb, S. (2017) Influence of humic acid application on phenology, leaf area and production duration of okra (Abelmoschus esculentus L.) cultivars. Pure Appl. Biol. 6, 1010-1020.

Hernandez, O.L., Calderín, A., Huelva, R., MartínezBalmori, D., Guridi, F., Aguiar, N.O., Olivares, F.L., Canellas, L.P. (2015) Humic substances from vermicompost enhance urban lettuce production. Agron. Sustainable Dev. 35, 225-232.

Ibrahim, S.M., Ali, A.M. (2018) Effect of potassium humate application on yield and nutrient uptake of maize grown in a calcareous soil. Alexandria Science Exchange Journal, 39, 412-418.

Jha, C.K., Saraf, M. (2015) Plant growth promoting Rhizobacteria (PGPR): a review. J. Agric. Res. Devel. 5, 108-119.

Joshi, M., Timilsena, Y., Adhikari, B. (2017) Global production, processing and utilization of lentil: A review. J. Integr. Agric. 16, 2898-2913.

Kabir, M.H., Das, P., Islam, M.M., Hossain, M.B., Mamun, A.N.K., Roland, V.R. (2019) Effect of different doses of nitrogen on nitrogen fixation and yield of lentil using tracer technique. GSC Biol. Pharm. Sci. 6, 069-075.

Kahraman, A. (2016) Effect of humic acid doses on yield and quality parameters of cowpea [Vigna unguiculata (L.) Walp] cultivars. Legume Research - An International Journal, 40, 155-159.

Kahraman, A. (2017) Effect of humic acid applications on the yield components in chickpea. Journal of Agricultural Faculty of Gaziosmanpasa University, 34, 218-222.

Karcher, D.E., Richardson, M.D. (2003) Quantifying turfgrass color using digital image analysis. Crop Sci. 43, 943-951.

Korir, H., Mungai, N.W., Thuita, M., Hamba, Y., Masso, C. (2017) Co-inoculation effect of rhizobia and plant growth promoting rhizobacteria on common bean growth in a low phosphorus soil. Frontiers Plant Sci. 8, Article 141.

Kumar, S.C., Maiti, S.K. (2013) Soil dehydrogenase enzyme activity in natural and mine soil - A review. Middle-East Journal of Scientific Research, 13, 898-906.

Lugtenberg, B., Kamilova, F. (2009) Plant-growthpromoting rhizobacteria. Ann. Rev. Microbiol. 63, 541-556.

Luz, W.C.d. (2001) Evaluation of plant growthpromoting and bioprotecting rhizobacteria on wheat crop. Fitopatol. Bras. 26, 597-600.

Lyons, G., Genc, Y. (2016) Commercial humates in agriculture: Real substance or smoke and mirrors? Agronomy, 6, 1-8.

MacCarthy, P. (2001) The principles of humic substances: An introduction to the first principle. Soil Science, 166, 738-751.

Marschner, H. (1995) "Mineral Nutrition of Higher Plants". London: Academic Press.

Muscolo, A., Sidari, M., Nardi, S. (2013) Humic substance: Relationship between structure and activity. Deeper information suggests univocal findings. J. Geochem. Explor. 129, 57-63.

Page, A.L., Miller, R.H., Keeney, D.R. (1982) "Methods of Soil Analysis, Part 2: Chemical and Microbiological Properties". Madison Wisconsin, USA: Soil Sci. Amer.

Palanivell, P., Susilawati, K., Ahmed, O.H., Majid, N.M. (2013) Compost and crude humic substances produced from selected wastes and their effects on Zea mays L. nutrient uptake and growth. Sci. World J. 2013, 276235.

Pasley, H.R., Cairns, J.E., Camberato, J.J., Vyn, T.J. (2019) Nitrogen fertilizer rate increases plant uptake and soil availability of essential nutrients in continuous maize production in Kenya and Zimbabwe. Nutr. Cycling Agroecosyst. 115, 373389.

Pérez-Montaño, F., Alías-Villegas, C., Bellogín, R.A., del Cerro, P., Espuny, M.R., Jiménez-Guerrero, I., López-Baena, F.J., Ollero, F.J., Cubo, T. (2014) Plant growth promotion in cereal and leguminous 
agricultural important plants: From microorganism capacities to crop production. Microbiol. Res. 169, 325-336.

Pinton, R., Cesco, S., Iacolettig, G., Astolfi, S., Varanini, Z. (1999) Modulation of $\mathrm{NO}^{3-}$ uptake by water-extractable humic substances: involvement of root plasma membrane $\mathrm{H}^{+}$ATPase. Plant Soil 215, 155-161.

Piper, C.S. (1950) "Soil and Plant Analysis". New York. USA: Interscience Puplishers Inc.

Pukalchik, M., Kydralieva, K., Yakimenko, O., Fedoseeva, E., Terekhova, V. (2019) Outlining the potential role of humic products in modifying biological properties of the soil: A review. Frontiers in Environmental Science, 7, 1-10.

Reimann, S., Sikora, R.A. (2003) Managing the mycorrhizosphere-an approach to sustainable agriculture after the phaseout of methyl bromide? Commun. Agric. Appl. Biol. Sci. 68, 34-129.

Rhezali, A., Lahlali, R. (2017) Nitrogen (N) mineral nutrition and imaging sensors for determining $\mathrm{N}$ status and requirements of maize. Journal of Imaging, 3, 1-10.

Rizk, A.M.A., Desoky, A.H., Badawi, F.S.F., Morsy, A.R. (2011) Response of two lentil varieties to coinoculation with Rhizobium and rhizobacteria in calcareous soil. Egypt. J. Appl. Sci. 26(3), 265- 283.

Rose, M.T., Patti, A.F., Little, K.R., Brown, A.L., Jackson, W.R., Cavagnaro, T.R. (2014) A metaanalysis and review of plant-growth response to humic substances. Adv. Agron. 124, 37-89.

Shen, D. (1997) Microbial diversity and application of microbial products for agricultural purposes in China. Agriculture, Ecosystems \& Environment, 62, 237-245.

Shen, W., Lin, X., Shi, W., Min, J., Gao, N., Zhang, H., Yin, R., He, X. (2010) Higher rates of nitrogen fertilization decrease soil enzyme activities, microbial functional diversity and nitrification capacity in a Chinese polytunnel greenhouse vegetable land. Plant Soil, 337, 137-150.

Singh, I. (2018) Plant growth promoting rhizobacteria (PGPR) and their various mechanisms for plant growth enhancement in stressful conditions: A review. Eur. J. Biol. Res. 8, 191-213.

Snedecor, G.W., Cochran, W.G. (1980) "Statistical Methods", $7^{\text {th }}$ ed., Iowa State Univ. Press, Ames, Iowa, USA.

Sun, R., Zhang, X.-X., Guo, X., Wang, D., Chu, H. (2015) Bacterial diversity in soils subjected to long-term chemical fertilization can be more stably maintained with the addition of livestock manure than wheat straw. Soil Biol. Biochem. 88, 9-18.

Taalab, A.S., Ageeb, G.W., Siam, H.S., Mahmoud, S.A. (2019) Some characteristics of calcareous soils. A review. Middle East Journal of Agriculture Research, 8, 96-105.

Tan, K.H., Tantiwiramanond, D. (1983) Effect of humic acids on nodulation and dry matter production of soybean, peanut, and clover. Soil Sci. Soc. Am. J. 47, 1121-1124.

Trevisan, S., Francioso, O., Quaggiotti, S., Nardi, S. (2010) Humic substances biological activity at the plant-soil interface: from environmental aspects to molecular factors. Plant Signaling Behav. 5, 635643.

Tripura, P., Verma, R., Kumar, S., Balwan (2017) Effect of potassium humate and bio-inoculants on growthand yield of cowpea (Vigna unguiculata (L.) Walp). Environment \& Ecology, 35, 1494-1498.

Tufail, M., Nawaz, K., Usman, M. (2014) Impact of humicacid on the morphologyvand yeild of wheat (Triticum aestivum L.). World Appl. Sci. J. 30, 475480.

Vacheron, J., Desbrosses, G., Bouffaud, M.L., Touraine, B., Moenne-Loccoz, Y., Muller, D., Legendre, L., Wisniewski-Dye, F., Prigent-Combaret, C. (2013) Plant growth-promoting rhizobacteria and root system functioning. Front. Plant Sci. 4, 356.

Vincent, J.M. (1970) "A Manual for the Practical Study of the Root Nodule Bacteria". I.B.P. Handbook, No. 15. Oxford, UK: Blackwell Scientific Publishers.

Zuffo, A.M., Steiner, F., Busch, A., Zoz, T. (2018) Response of early soybean cultivars to nitrogen fertilization associated with Bradyrhizobium japonicum inoculation. Pesquisa Agropecuária Tropical, 48, 436-446.

Egypt. J. Agron. 43, No. 1 (2021) 


\section{استجابة العدس للهيومات الخام و للتلقيح ببكتريا الجذور تحت ظروف الأراضي الجيرية

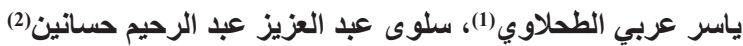

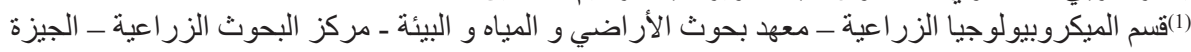

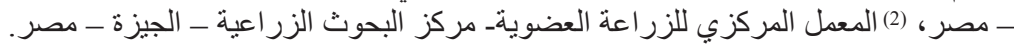

تم إقامة تجربتين حقليتين خلال موسمين شتويين (2018/2019 و 2019/2020) لدر اسة زراء اعة صناء صنفين

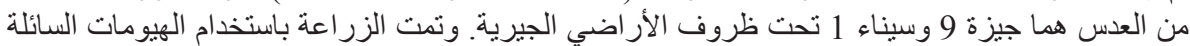

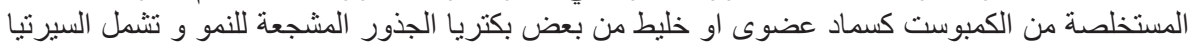

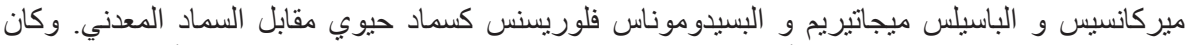

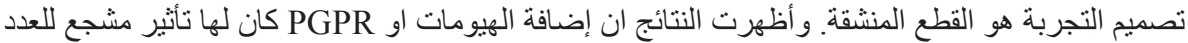

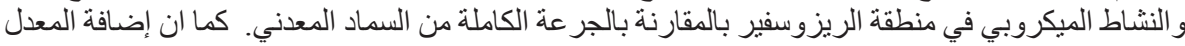

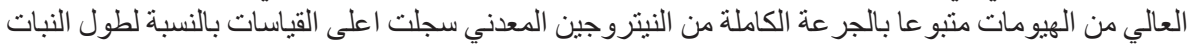

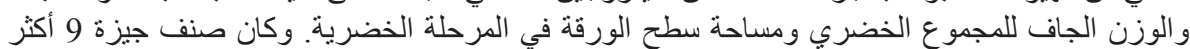

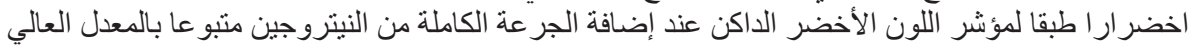

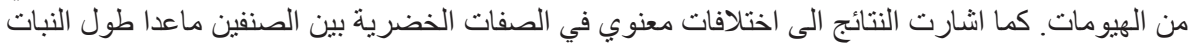

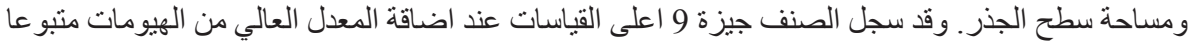

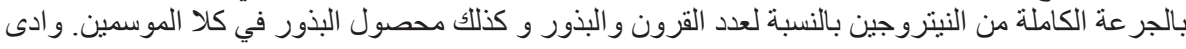

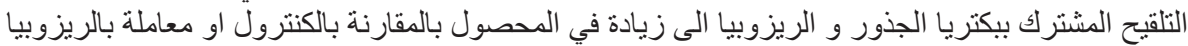

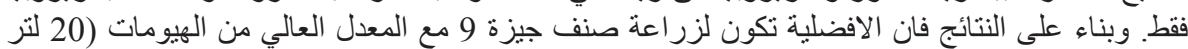
للفدان) مع التلقيح بالريزوبيا تحت ظروف الافية الأر اضي الجيرية. 